\title{
Archaeobotanical studies at Sumaki Höyük (Batman, Turkey) in 2014
}

\author{
Leman Kutlu ${ }^{1}$, Aslı Erim Özdoğan², Ernaz Altundağ Çakır ${ }^{3 *}$ \\ ${ }^{1}$ Department of Biology, Institute of Science, Duzce University, 81620, Duzce. \\ ${ }^{2}$ Department of Archeology, Faculty of Arts and Science, Çanakkale 18 Mart University, 17000, Çanakkale. \\ $3^{*}$ Department of Biology, Faculty of Arts and Science, Duzce University, 81620, Duzce.
}

Corresponding Author: ernazaltundag@duzce.edu.tr

\begin{abstract}
Our study focuses on the archaeobotanical analyses of 2014 season of the Sumaki Höyük, which is located east of Beşiri town in Batman province. It was excavated within the framework of Ilısu Dam and HES project by the Batman Museum at the charge of Dr. Aslı Erim Özdoğan. Sumaki Höyük yields Late Pre-Pottery Neolithic B (LPPNB) and Early Pottery Neolithic, namely Pre-Proto Hassuna and Proto Hassuna phases, dated to 7310 - 7040 cal BC - $6480-6400 \mathrm{cal}$ BC. The uppermost phase is a small farm or a district belongs to Abbasid / Hamdani Periods dated to cal. 770-890 AD. Most of the 2014 botanical samples are collected from the phases dated between cal. 7030-6580 BC and cal. 6830-6470 BC. The archaeobotanical remains were obtained by flotation of 348 lt soil of 45 samples that were collected from different loci at Sumaki Höyük. The remains are preserved either by carbonizing or mineralizing. Two domesticated families Poaceae and Fabaceae are predominant. The earliest domesticated form of wheat Triticum dicoccon (Schrank) Schübl. grains, as well as pieces of spikelet forks, are determined. Among the Fabaceae family Lens culinaris Medik. (lentil), Vicia ervilia (L.) Willld. (bitter vetch), Pisum sativum L. (garden pea) and Cicer arietinum L. (chickpea) species were vegetal source of nutrition of seminomadic inhabitants of Sumaki Höyük. The existence of Linum L. (Linen) might be the indicator of weaving and/or oil consumption.
\end{abstract}

Keywords: Archaeobotany, Sumaki Höyük, Batman, Turkey

\section{Özet}

Bu çalışmada, Ilısu Barajı ve HES Projesi kapsamında, Dr. Aslı Erim-Özdoğan'ın bilimsel başkanlığında Batman Müzesi tarafından kazılan, Batman ili Beşiri İlçesi'nde yer alan Sumaki Höyük'ün 2014 yılı arkeobotanik verileri ele alınmıştır. Sumaki Höyük Neolitik Dönem tabakaları cal MÖ 7310 - 7040 ile cal MÖ 6480 - 6400 tarihleri arasında Son Çanak Çömleksiz Neolitik B (LPPNB) ve Pre-Proto Hassuna ile Pre Hassuna evrelerini içerir. Höyüğün en üst yerleşimi cal. MS 770-890 tarihlenen Abbasid / Hamdani Dönemlerine ait bir kaç haneli bir mezraa veya bir çiftliktir. 2014 botanik örnekleri cal. MÖ 7030-6580 ve cal. MÖ 6830-6470‘ye tarihlenen tabakalardan toplanmıştır. 45 toprak örneğinden, 348 litre toprağın yüzdürülmesiyle elde edilmiştir. Kalıntılar karbonlaşarak ve mineralize şeklinde günümüze ulaşmıştır. Örnekler içinde kültüre alınmış Poaceae ve Fabaceae familyaları yoğunluktadır. Buğdayın tarıma alınmış erken formlarından olan Triticum dicoccon (Schrank) Schübl. taneleri ve başakçık parçaları bulunmuştur. Saptanan tohumlar arasında Lens culinaris Medik. (mercimek), Vicia ervilia (L.)Willld. (acı burçak), Pisum sativum L. (bezelye) ve Cicer arietinum L. (nohut) türlerinin bulunması Sumaki Höyük’ün yarı göçebe sakinlerinin tükettikleri bitkiler hakkında ipuçları vermektedir. Linum L. (Keten) bitkisinin ise dokuma ve/veya yağ elde etme amacıyla kullanıldığı düşünülmektedir.

Anahtar Sözcükler: Arkeobotanik, Sumaki Höyük, Batman, Türkiye 


\section{Introduction}

Plants play an important role in humans' life for millions of year, not only for nutrition but also for medical uses, for construction dwellings, for weaving (Nesbitt, 1995). Many plants, which are in our kitchen today were first domesticated in the Near East. Researches in the Central Anatolia, the North Mesopotamia and the Levant show us that cereals, pulses, pistachio, almond, and linen were first domesticated in these regions and over time distributing to all Europe and the Caucasus, later to far regions (Bingham et al. 2012).

Archaeobotany was improved as an archaeologic subbranch of Paleobotany (Hastorf, 1999). It is called Paleoethnobotany in the New World and defined as analyses and interpretation of the archaeobotanical remains to understand the interrelations of plants and humans (Hastorf and Popper, 1988). Besides, it is also defined as analyzes of the plant remains preserved in the archaeological layers, which were either consumed or cultivated (Renfrew, 1973).

This paper deals with the archaeobotanical analyses of carbonized and mineralized plant remains secured from the prehistoric phases of Sumaki Höyük. Sumaki Höyük, in the drainage basin of the Ilısu Dam waters, is situated east of Beşiri town in eastern Batman province, at the mouth of the Garzan basin, where the Garzan River realizes a wide curve, between 700-710 meters, on the Plio-Quaternary base flat that looks like an erosion berm suspended on old Eocene-Upper Miocene limestone outcroppings (Figure 1). The dimensions of the settlement, positioned on the mountain-plain transition zone, are approximately $160 \mathrm{~m}(\mathrm{~N}-\mathrm{S})$ to $130 \mathrm{~m}(\mathrm{E}-\mathrm{W})$, and the thickness of the fill varies between 2.30 and 2.40 meters. The site is bordered by the Kani Huşur (Cadalı Stream) in the north, its other sides today are bordered by agricultural fields. The site was excavated between the years 2007-2010 and 2014. Sumaki Höyük yields Late Pre-Pottery Neolithic B (LPPNB) and Early Pottery Neolithic, namely Pre-Proto Hassuna and Proto Hassuna phases, dated to 7310 - $7040 \mathrm{cal} \mathrm{BC} \mathrm{-} 6480$ - $6400 \mathrm{cal} \mathrm{BC}$. The uppermost phase is a small farm or a district belongs to Abbasid / Hamdani Periods dated to 770-890 cal. AD. Sumaki was not occupied between the Early Pottery Neolithic and the Early Middle Ages. Neolithic Period, which is the main period of Sumaki has been exposed in a wide exposure $\left(2150 \mathrm{~m}^{2}\right)$. The assemblages and settlement patterns of the 6 phases are totally different, evince sedentary, semi-nomadic or nomadic lifestyles. Archaeological records of Sumaki also witness Holocene climatic fluctuations and their impact (Erim-Özdoğan 2011).

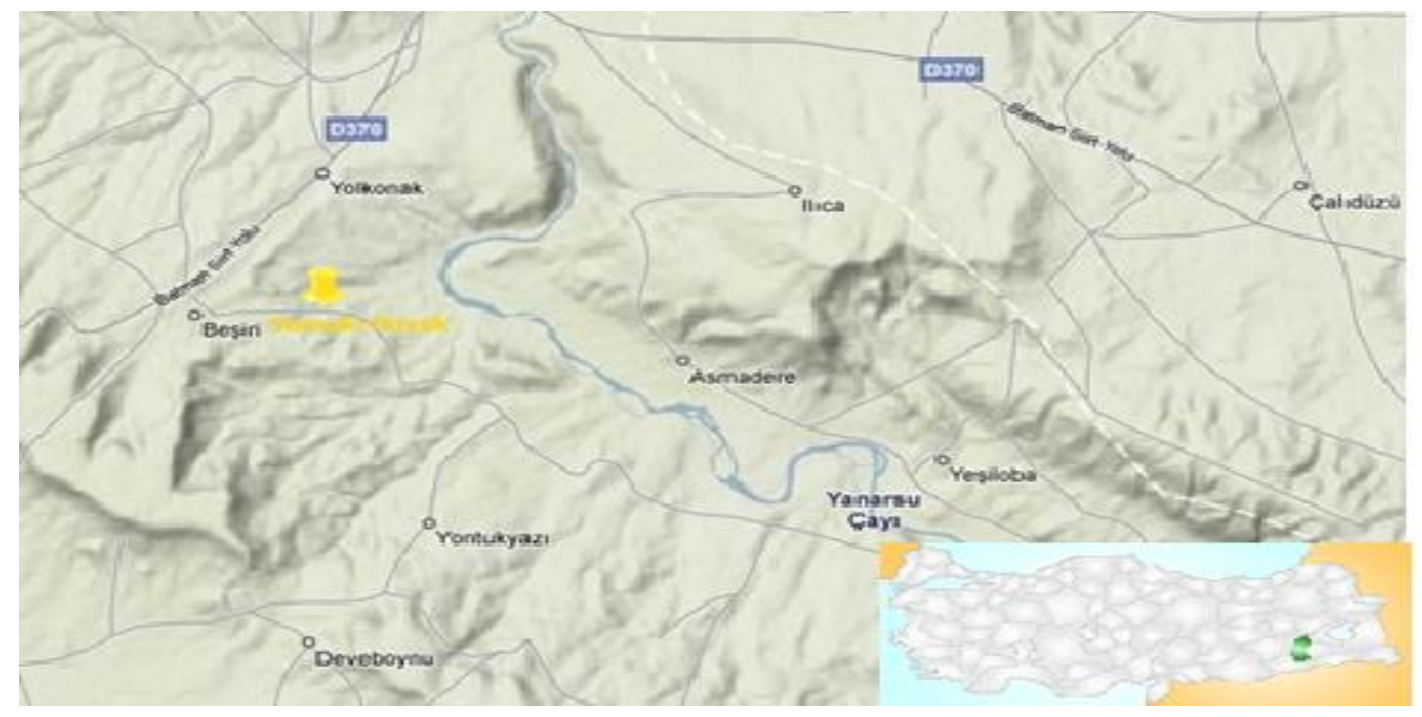

Figure 1: Location of Sumaki Höyük 


\section{Material and Methods}

45 samples from various locations collected in 2014 season of Sumaki Höyük were analyzed. Features like ashy areas, fire pits, deposits of hearths and ovens, etc. were chosen for sampling by the archaeologists in the field. Each sample is not less than 3 lt. Every sample has a tag comprises of all the information of the locus (date, trench, feature no, level, grid, elevation, etc.). All samples were processed through flotation and sieving. 348 liter of soil were floated in the flotation tank.

After floatation two different materials were obtained as heavy and light materials. Even both yields plant remains, seed remains were mainly in the light materials. After being dried, both were sieved in sieves with $>4,>2,>1$ and $>0.5 \mathrm{~mm}$. The plant remains and other materials (sherds, burnt mudbrick particles, obsidian, flint, etc.) were separated.

The samples, which were prepared for laboratory study in the Sumaki excavation house, were delivered to the Botanical Research Laboratory of the Biology Department of Düzce University. In the laboratory, the plant remains were reprocessed for separation of wood, straw, seed and nut fragments with the help of stereomicroscope. "A Manual for the Identification of Plant Seeds and Fruits (2013)", and "Handbook of Plant Palaeoecology (2012)" were used as references for determination of seeds. Scientific plant names were checked by using Plant List website (www.theplantlist.org).

The number of seeds in each sample were recorded. Not all seeds are intact, but the broken ones were also counted as forming intact. Samples, which are kept in Eppendorf tubes in plastic bag with its Latin name, are all stored in the Botanical Research Laboratory of the Biology Department of Düzce University. Photographs were taken with a digital camera connected to the stereomicroscope.

\section{Results and Discussion}

The data were obtained from analyzing of the 45 samples collected from various loci at Sumaki Höyük in 2014 (Table 1). Poaceae and Fabaceae are predominant among the remains.

a) Cereals (Poaceae)

All the cereals of Poaceae family were carbonized. The genera of the eleven seeds from the Poaceae family cannot be identified. Three seeds were counted as Triticum. 168 remains were listed as Triticum/Hordeum being barley or wheat.

Hordeum vulgare L.: A part of barley was found as separated from outer testa and the other part were found without husk. Among the four barley seeds, two are with husk, and two are without.

Triticum dicoccon (Schrank) Schübl.: Fourteen emmer wheat were determined and there are 74 pieces of Spikelet fork from emmer samples (Figure 2a-c).

Lolium temulentum L.: Two seeds in wild form (Figure 2d). 

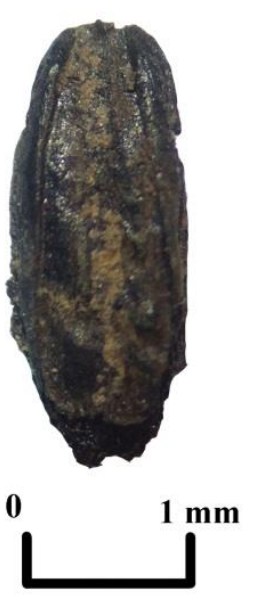

2.a.
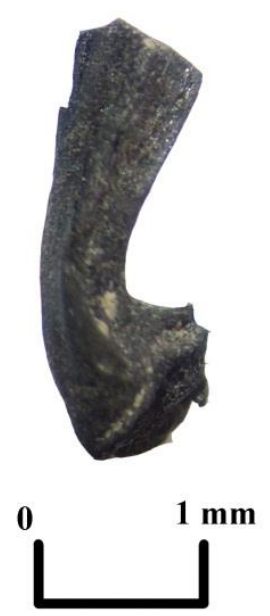

2.b.
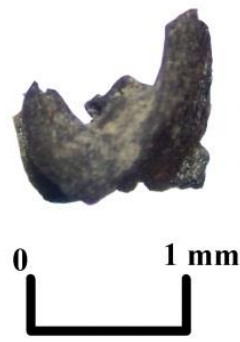

2.c.

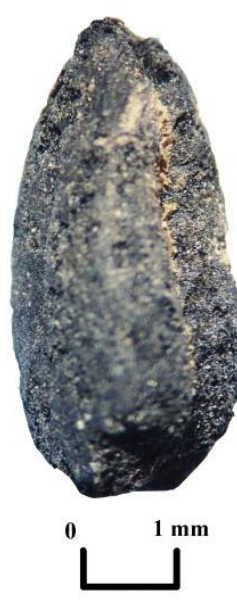

2.d.

Figure 2.a. Triticum dicoccon, b-c. Spikelet forks of Triticum dicoccon, d. Lolium temulentum

b) Legumes (Fabaceae)

Cicer arietinum L.: It is represented by 2 chickpea seeds.

Lathyrus sativus L.: 2 seeds are identified (Figure 3a, 3b).

Lens culinaris Medik.: Lentil seeds are predominant in Fabaceae family. It is represented by 80 seeds, of which 49 are intact (Figure 3c).

Vicia ervilia (L.) Willd.: 6 seeds are identified as vetch (Figure 4a).

Pisum sp.: Only 2 seeds are detected (Figure $4 b$. .).
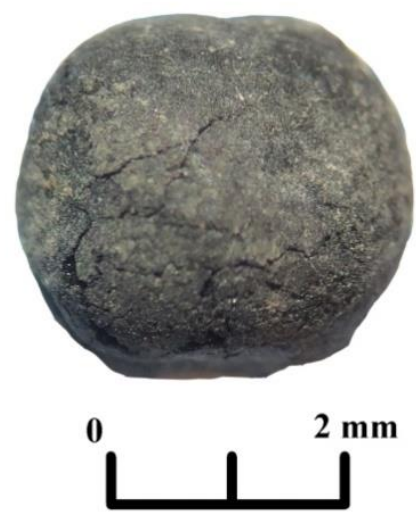

3.a.
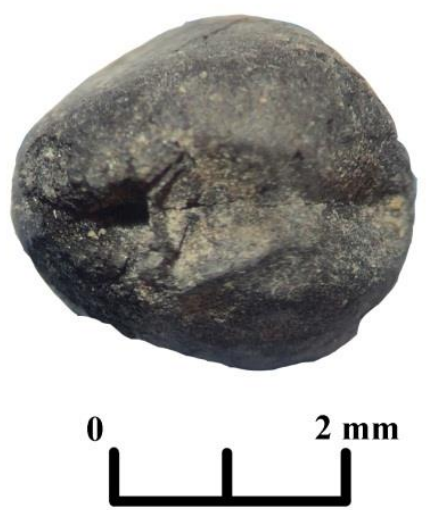

3.b.
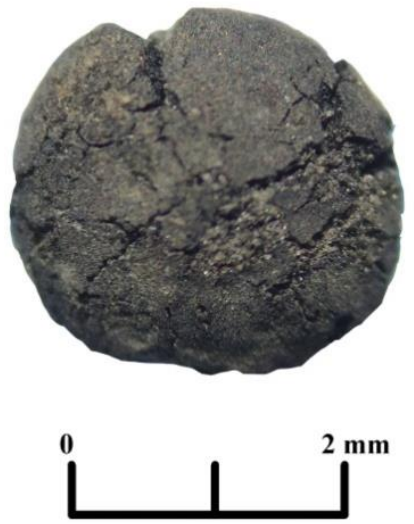

3.c.

Figure 3.a-b. Lathyrus sativus, c. Lens culinaris 

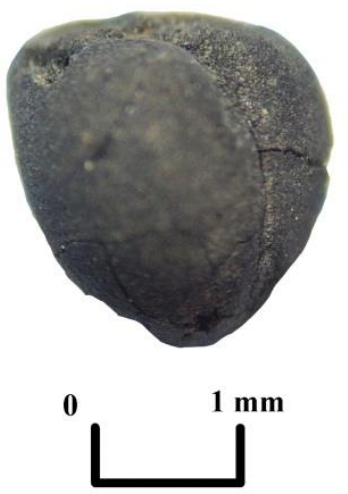

4.a.

Figure 4.a. Vicia ervilia, b. Pisum sativum

c) Other Legumes (Fabaceae)

6 seeds are Medicago sp. (Figure 5), and 5 seeds are Medicago radiata L.. 80 broken seeds were identified in Fabaceae. 4 seeds that cannot be identified either as Lathyrus sativus L. or Vicia ervilia (L.) Willd. are shown together in the list (Table 1).

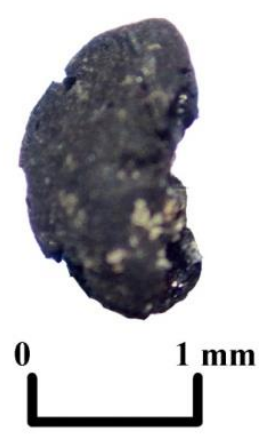

Figure 5. Medicago sp.

d) Linseed (Flax)

Linum: 15 linen seeds are identified (Figure 6).

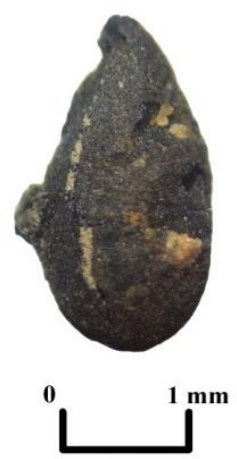


Figure 6. Linum sp.

e) Fruits

Even there are some fragments of fruit seeds only two of them can be identified as fig (Ficus carica).

f) Wild Plant Taxa

Other identified seeds, which give information about the ancient flora of the study area are; Centaurea sp. (1), Euphorbiaceae (1), Euphorbia falcata L. (1), Rumex sp. (2), Boraginaceae (1), Chrozophora tinctoria (L.) A. Juss. (11), Brassicaceae (1), Cyperaceae (3) and Ziziphora sp. (1). Chrozophora tinctoria and Boraginaceae seeds were mineralized, the rest are carbonized (Table 1). Habitat is wetland. The Sumaki Höyük botanical samples are taken from different contexts like ash pits, fire pits, deposits of hearths and ovens, ashy areas and/or burnt ashy jug.

Since only spikelet forks of the emmer wheat have been detected, it is not satisfactory to claim the existence of agricultural activities of Sumaki people.

Fabaceae is the most consumed family and the cereals are the second. Lentil is significant because of its quantity (Figure 7).

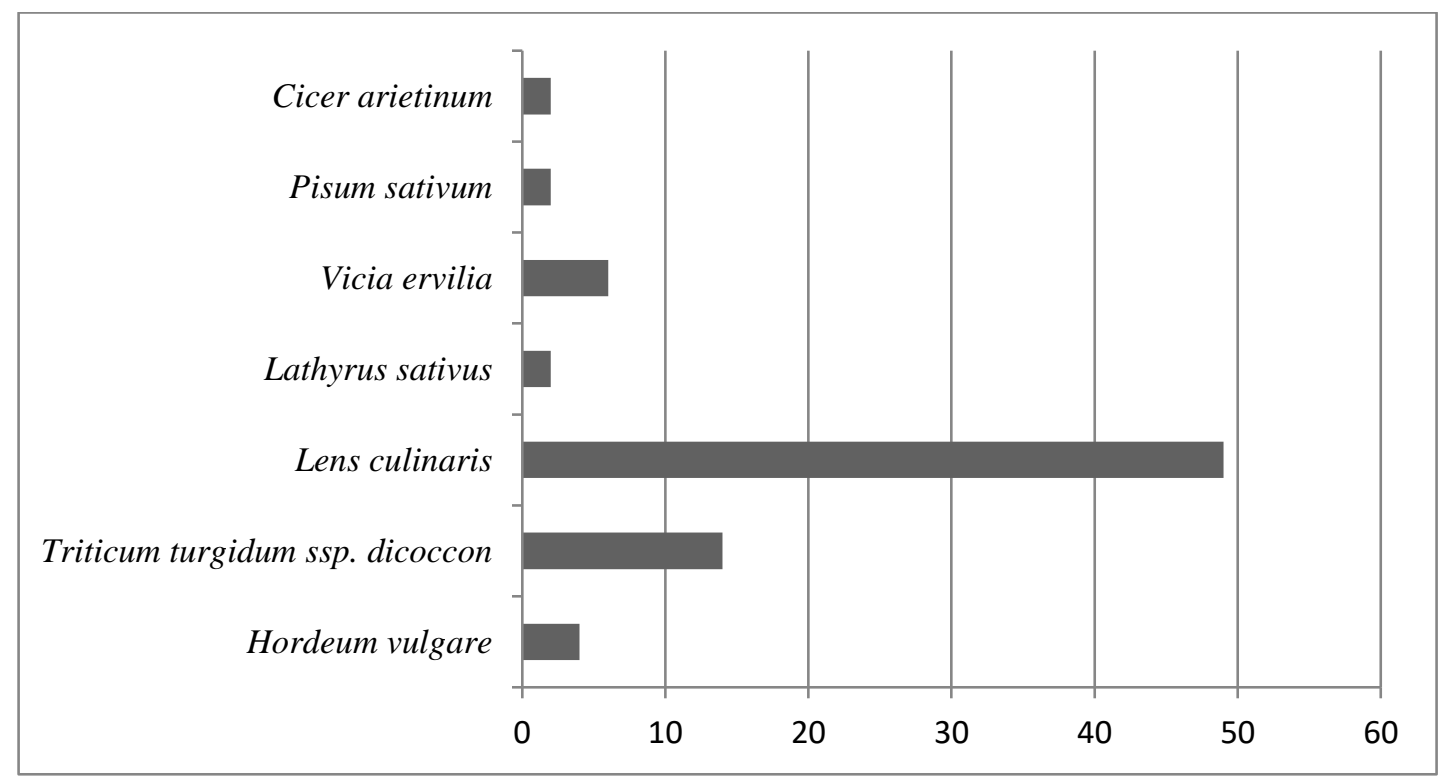

Figure 7. Economic crops of Sumaki Höyük

\section{Conclusions}

The archaeobotanical remains of 2014 season of Sumaki Höyük do not display any hint of agricultural activities for LPPNB and Early Pottery Neolithic phases of the site. We compared our results with Çayönü Tepesi (Ergani, Diyarbakır) and Salat Camii Yanı (Bismil, Diyarbakır) reports which are in the similar sub-phase and close localities with Sumaki Höyük (Table 2).

Ergani Plain and Lower Garzan Basin, which are situated in the mountain-plain transition zone of Upper Mesopotamian part of Southeast Anatolia is considered to be in the Irano-Turanian subregion in terms of its present-day natural vegetation (Zohary 1973). The plant remains of Çayönü prove that between 10,000 - 7500 BP Ergani Plain was covered with open forests of oak-juniper (oak-juniper open forest zone) and further south there was a transitional "almond-pistachio forest-steppe zone, as well as rich in legumes such as lentils and vetch, herbaceous looking cereals such as emmer and einkorn, also other herbaceous plants (van Zeist and de Roller 1994). 
Table 1. Plant remains of Sumaki Höyük

\begin{tabular}{|c|c|c|c|}
\hline Name & Plant Part & Preservation & Amount \\
\hline Centaurea sp. & Seed & Carbonized & 1 \\
\hline Cicer arietinum & Seed & Carbonized & 2 \\
\hline Fabaceae & Seed & Carbonized & 80 \\
\hline Ficus carica & Seed & Carbonized & 2 \\
\hline Hordeum vulgare & Fruit & Carbonized & 4 \\
\hline Lens culinaris & Seed & Carbonized & 49 \\
\hline Triticum dicoccon & Spikelet fork & Carbonized & 74 \\
\hline Triticum dicoccon & Fruit & Carbonized & 14 \\
\hline Poaceae & Fruit & Carbonized & 11 \\
\hline Triticum/Hordeum & Fruit & Carbonized & 168 \\
\hline Triticum sp. & Fruit & Carbonized & 3 \\
\hline Linum sp. & Seed & Carbonized & 15 \\
\hline Medicago sp. & Seed & Carbonized & 6 \\
\hline Medicago radiata & Seed & Carbonized & 5 \\
\hline Euphorbia falcata & Seed & Carbonized & 1 \\
\hline Rumex sp. & Seed & Carbonized & 2 \\
\hline Lolium temulentum & Fruit & Carbonized & 2 \\
\hline Boraginaceae & Seed & Mineralized & 1 \\
\hline Chrozophora tinctoria & Seed & Mineralized & 11 \\
\hline Lathyrus sativus & Seed & Carbonized & 2 \\
\hline Euphorbiaceae & Seed & Carbonized & 1 \\
\hline Brassicaceae & Seed & Carbonized & 1 \\
\hline Cyperaceae & Seed & Carbonized & 3 \\
\hline Lathyrus/Vicia & Seed & Carbonized & 4 \\
\hline Vicia ervilia & Seed & Carbonized & 6 \\
\hline Fruit & & Carbonized & 2 \\
\hline Pisum sativum & Seed & Carbonized & 2 \\
\hline Ziziphora sp. & Seed & Carbonized & 1 \\
\hline
\end{tabular}

Even though the natural flora of the Lower Garzan Plain has not been studied properly, and the plant remains of 2 nd and 1 st millenium BC of Çemialo Sırt1, which is situated in the mid part of the Lower Garzan Basin contains similar data with Sumaki, especially the existence of lentil (Lens culinaris), barley (Hordeum vulgare), pea (Pisum sativum), chickpea (Cicer arietinum), bitter vetch (Vicia ervilia), grasspea (Lathyrus sativus), grape (Vitis vinifera), fig (Ficus carica), hackberry (Celtis australis), goose grass (Galium), trefoil (Trifolium), mallow (Malva), einkorn/durum wheat (Triticum aestivum/durum), and einkorn wheat (Triticum aestivum).

Salat Camii Yanı, which is located about $20 \mathrm{~km}$ east of Bismil in Diyarbakır province is a Pottery Neolithic site, excavated within the frame of Ilisu Dam project between the years 2004 to 2009. The thickness of its deposit is ca. 4,50 m. and has 12 layers and three Pottery Neolithic phases (Phase 1 
(earliest), Phase 2, and Phase 3 (latest), based on analysis of pottery. Its assemblage (architecture, pottery, and other artifacts) show similarities to the assemblage of Sumaki Höyük as well as its dates Salat Camii Yanı Project (2010).

Table 2. Comparasion of Sumaki Höyük and Çayönü Tepesi

\begin{tabular}{|c|c|c|c|}
\hline Plant Name & $\begin{array}{l}\text { Number of seeds } \\
\text { (Sumaki Höyük) }\end{array}$ & $\begin{array}{l}\text { Number of seeds } \\
\text { (Çayönü Tepesi) }\end{array}$ & $\begin{array}{l}\text { Number of seeds } \\
\text { (Salat Camii Yanı) }\end{array}$ \\
\hline Triticum monococcum/dicoccum & - & 1 & $143 / \pm 400$ \\
\hline Triticum dicoccon & 14 & 36 & - \\
\hline Triticum sp. & - & 181 & - \\
\hline Triticum dicoccon spikelet forks & 74 & - & - \\
\hline Triticum spikelet forks & - & 260 & - \\
\hline Hordeum sp. & 4 & 1.3 & $51 / 1 \mathrm{cf}$. \\
\hline Pisum sp. & 2 & 43 & 2 \\
\hline Lens sp. & 49 & 74.2 & 8 \\
\hline Vicia ervilia & 6 & 3823.5 & - \\
\hline Cicer sp. & 2 & 7.5 & $3 / 2 \mathrm{cf}$. \\
\hline Linum sp. & 15 & 0.3 & 29 \\
\hline Pistacia sp. nutshell fragments & - & $\mathrm{xx}$ & $25 / 9.4 \mathrm{cf}$. \\
\hline Amygdalus sp. nutshell fragments & - & $\mathrm{x}$ & - \\
\hline Vicia sp. & - & 142 & 3 \\
\hline Lolium sp. & 2 & 7.9 & $1 \mathrm{cf}$. \\
\hline Bromus sp. & - & 3 & 7 \\
\hline Chrozophora sp. & 11 & 4 & - \\
\hline Rumex sp. & 2 & 3 & - \\
\hline Ziziphora sp. & 1 & 2 & $30 / 18$ cf. \\
\hline Centaurea sp. & 1 & - & 1 \\
\hline Euphorbiaceae & 1 & - & - \\
\hline Euphorbia falcata & 1 & - & - \\
\hline Boraginaceae & 1 & - & - \\
\hline Brassicaceae & 1 & - & - \\
\hline Cyperaceae & 3 & - & 5 \\
\hline Lathyrus sp. & 2 & & 6 \\
\hline Medicago sp. & 11 & - & 10/1 cf. \\
\hline Ficus sp. & 2 & - & $3 / 2 \mathrm{cf}$. \\
\hline
\end{tabular}

cf: indicate that the sample includes items not clearly identifiable, estimates based upon quantities of nutshell remains and sample frequencies; $x$ : present; $x x$ : fairly common.

\section{Abbreviations}

N-S: North-South

E-W: East-West

LPPNB: Late Pre Pottery Neolithic B

BC: Before Christ

AD: Anno Domini

Cal.: Calibrated

The similarity of the archaeobotanical remains of the three localities was very clear because of their same geopraphical region and terms. Even though consumption of legumes and grains were common in three of sites, legumes were more prevalent than grains in Çayönü settlement (Table 2). According to the comparison, the consumption of legumes and cereals, which are the main food plants were very common. According to Table 2, the number of legumes was more than cereals, although the number of 
cereals was more than legumes in the Sumaki Höyük and Salat Camii Yanı centers. Due to that Sumaki Höyük and Salat Camii Yanı reports were known as preliminary reports, it could be not enough for conclusion.

Another noteworthy difference between the comparison centers is the consumption of pistachio (Pistacia sp.) and almond (Amygdalus sp.) in Çayönü, and pistachio (Pistacia sp.) in Salat Camii Yanı. These seeds have not been determined in Sumaki Höyük. It could be because of the plant remains were collected only for one single term in Sumaki Höyük.

The material of Sumaki Höyük is not extensive for classification of plant breeding in LPPNB hence it was collected for single season in 2014.

\section{Acknowledgements}

We would like to thank Prof. Dr. René Cappers for his help for determining the seeds.

\section{References}

Bingham, J., Chandler, F., Chisholm, J., Harvey, G., Miles, L., Reid, S., Taplin, S. (2012). Antik Dünya Ansiklopedisi. Tübitak Popüler Bilim Kitapları, Ankara, pp. 10-11.

Erim, Özdoğan, A. (2011). Sumaki Höyük: A New Neolithic Settlement in the Upper Tigris Basin. In: M. Özdoğan, N. Başgelen and P. Kuniholm (Eds.), The Neolithic in Turkey New Excavations \& New Researches, The Tigris Basin. Archaeology \& Art Publications, İstanbul, pp. 19-60.

Hastorf, C. A., and Popper, V. S. (1988). Current Palaeoethnobotany: Analytical Methods and Cultural Interpretations of Archaeological Plant Remains. University of Chicago Press. Chicago, USA.

Hastorf, C.A. (1999). Recent Research in Palaeoethnobotany. Journal of Archaeological Research, 7(1), 55-103. Nesbitt, M. (1995). Plants and People in Ancient Anatolia. The Biblical Archaeologist, 58(2), 68-81.

Renfrew, J.M. (1973). Palaeoethnobotany: The Prehistoric Food Plants of the Near East and Europe. Columbia University Press.

Salat Camii Yanı Project (Internet), (2010). http://rcwasia.hass.tsukuba.ac.jp/scy/ (visited on 20.12.2017).

The Plant List (Internet), (2013). http://www.theplantlist.org (visited on 01.01.2018).

van Zeist, W., de Roller, G.J. (1994). The Plant Husbandry of Aceramic Çayönü, SE Turkey. Balkema, A.A. (Ed.), Palaeohistoria, Rotterdam, 65-96.

Zohary, M. (1973). Geobotanical foundations of the Middle East I-II. Stuttgart, Gustav Fischer Verlag and Amsterdam, Swets and Zeitlinger.

Submitted: 29.03 .2018

Accepted: 07.06 .2018 